\title{
The Voices of Midlife Women Facing Housing Insecurity in Victoria, Australia
}

\section{Andrea Sharam}

Institute for Social Research, Swinburne University of Technology

E-mail: asharam@swin.edu.au

Single, older women in the State of Victoria, Australia, have emerged as a group experiencing housing insecurity and being highly vulnerable to homelessness in their old age. A sizable demographic cohort, it is a group that could overwhelm the existing homelessness service system. One of the most surprising aspects of this trend is their propensity to be tertiary educated. Focus groups revealed 'critical life events' as significant, and a shared 'control belief' in the value of education. Given that education is a key means by which Australian governments seek to remedy homelessness, the entry of educated women into the homelessness population suggests policy needs to re-examine homelessness causation and explicitly apply a gender-lens.

Key words: Women, housing insecurity, critical life events, education, labour market flexibility.

\section{Introduction}

Single, older women in Australia have emerged as a group vulnerable to housing insecurity and being highly vulnerable to homelessness in later life (Crinall, 2001; Tually et al., 2007; Sharam, 2008, 2011; Beer and Faulkner, 2009; McFerran, 2010). Older, uneducated, single women who have worked throughout their lives are increasingly presenting to homelessness services (McFerran, 2010). Many older women were prevented from accumulating superannuation or other retirement savings as a result of public policy that forced them to leave certain types of employment (such as the Public Service) once they married, thus effectively locking them out of the labour market (Olsberg, 2004). They were consequently dependent on spousal incomes or welfare payments, such as they were at the time. The association between poverty and homelessness (Sharam and Hulse, 2014), and poverty and gender (Green, 2009), suggests their homelessness should not be surprising.

Australian policy and homelessness advocates share a 'loose consensus' that homelessness is caused by the interaction of individual factors such as mental health, drug and alcohol abuse, with structural factors such as the economy, including housing and labour markets, although there is a 'near total absence of work directly investigating structural drivers of homelessness in Australia' (Wood et al., 2014a: 17). In Australia, unlike Britain, there is no statutory right for homeless people to be assisted. The homelessness services system instead targets high needs groups such as older indigent men, young people, people with mental health problems, those with substance abuse issues, women escaping domestic violence and aboriginal people (AIHW, 2014). Until recently, older, single, low-needs women have not presented to homelessness services so have not been 
considered a group at risk. But it may, of course, be the case that they previously adopted strategies that rendered their homelessness invisible (Darab and Hartman, 2013).

An underlying assumption on the part of government is that homelessness often arises from personal deficits, a detachment from the labour market and over-reliance on welfare (Australian Government, 2008). The Australian, State and Territory Government's National Partnership Agreement on Homelessness (NPAH) accordingly includes education as a key means by which homelessness can be remedied (COAG, 2008). This understanding of the causes of and remedies for homelessness is, however, challenged by the increasing numbers of homeless and insecurely housed, low-needs, tertiary-educated women. Sharam's (2008) study of low-needs single women aged thirty-five to sixty-four found that more than two-thirds had post-secondary qualifications. A later survey of single women over forty years of age who believed they would not fully own a home by retirement age found three quarters of the women also had post-secondary qualifications (Sharam, 2011).

Governments in Australia have promoted a 'switch to asset-based welfare', through the exemption of the primary place of residence from the Age Pension test, allowing the age pension to be set a low level relative to other countries (Wood and Ong, 2012: 1). Yet housing prices have outstripped average incomes for many years, home ownership rates are declining and private rents are soaring. There are two immediate implications. Firstly, without an asset, such as a home, aged Australians will increasingly be at risk of homelessness. Secondly, education and employment take on greater importance as the primary means by which assets can be acquired and security in old age obtained. In Australia, education is a key determinate of lifetime earnings, yet while the educational attainment of Australian women is equal to, or outstrips that of men, women's wages are stubbornly and significantly unequal (WGEA, 2014).

In part, the vulnerability of older women is an issue of scale, with demographic and social change contributing to an increase in the number and proportion of older, single women in the population. The first of the post-World War II 'baby boom' generation have reached retirement, and women's greater longevity means there are more older women than older men. Older women represent a significant demographic cohort.

Secondly, in the life-course approach, households at midlife are consolidating: children have grown up and the mortgage burden is negligible. But this trajectory of a single marriage partnership over a lifetime now only reflects the circumstances of around half coupled Australian households. Increasingly, divorce and separation are the norm. Moreover, the growing number of lone person households contain people who have never married. Midlife therefore is increasingly a period of transition and disruption rather than, as in the life-course approach, one of wealth consolidation.

Social changes such as the availability of the contraceptive pill by the end of the 1960s; the introduction of no fault divorce, single mother's pensions, the ending of legal illegitimacy and free education in the mid-1970s; and equal opportunity and equal wages legislation in the 1980s have driven much of this disruption.

This article draws on unexpected findings of focus groups with single midlife, women in Australia's second most populous state, Victoria, which were held to improve understanding of the nexus between women's financial situations and housing, and what this means for their future (Sharam 2015). A 'critical life events' approach is used to understand the impact of the various disruptions described by participants. The focus group participants shared a 'control belief', concerning the value of education. Control 
beliefs are the 'emotional, motivational and epistemological beliefs ... [that] affect ... long term coping and resilience' that follow a critical life event (Turner et al., 2012: 215). The women often made substantial sacrifices in order to gain qualifications to improve their economic position. But this investment had not translated into a capacity to obtain sufficient housing equity to provide for economic security in their old age. Education and the resulting improvements to their earning capacity had not compensated for the accumulated impacts of previous critical life events and were undercut by changes to housing and labour markets. These latter critical life events undermined any hope of acquiring housing equity.

This article proceeds as follows. In the first section, the critical life events approach is introduced and a brief survey of the existing housing research reflecting the critical life events is provided. This is followed by the focus group findings concerning the impact of critical life events on housing, education and employment. Conclusions are then given.

\section{Critical life events}

Adverse critical life events are major 'experiences, which occur quite seldom but have a dramatic influence of [sic] one's life and require fundamental readjustment' (Stefanek et al., 2012: 202). The events can be normative, reflecting developmental or life-course milestones, such as graduation, obtaining a job, partnering, birth of children, and whilst such transitions are generally regarded as positive, they are also often stressful. Events can also be non-normative, such as loss of partner, death, disability, disaster or migration. Typically, critical life events alter the status quo, and frequently trigger further events. The impact of critical life events is known to be cumulative, often over long time periods. In economics, adverse critical life events are often associated with hysteresis. 'Hysteresis arises when a negative (positive) shock has long-lasting impacts so that when the shock is reversed, the affected person(s) does not return to the same position they were in before the shock' (Flatau et al., 2004: glossary).

The concept of 'critical life events' stems primarily from health and psychology to describe the interaction of events that have major impacts on peoples' lives, the ways individuals react to and manage these events, as well as some of the impacts of the combination of these events (Moloney et al., 2012). The way in which individuals experience adverse critical life events is influenced by personal and contextual circumstances (Baxter et al., 2012); coping strategies, personal appraisal of events (reflecting a person's 'control' beliefs or belief system) (Allen, 2000) and previous or current exposure to other events, along with command over material and non-material resources are each 'critical for adaptation' (Jopp and Schmitt, 2010). Successful responses to critical life events include the need for 'time, money, skills, [and the] cooperation of others' (Ajzak, 1991). The ability to avoid negative impacts of, or recover from, an adverse event (and mitigate the accumulative effects of events) relates to the risk of such events occurring and the availability and extent of insurance. Insurance mechanisms include savings and credit, and access to increased earnings, but also reflect market and socialised insurances, such as life insurance and unemployment benefits and informal insurances such as familial or friendship supports. Control beliefs tend to determine profligacy or frugality. Modified for sociological inquiries, the term has increasing relevance for interpreting the intersection of the life events and individuals' experience in the context of economic and social systems and individual agency in response, and their impact. 


\section{Critical life events and housing}

Housing researchers are increasingly interpreting household formation, dissolution, changing household composition and tenure change as events rather than normative life-course transitions (Wood and Ong, 2012), which affect the economies of scale in consumption available to individuals in group or multi-generational households. The ability to accumulate equity in housing, and/or acquire savings and cope with adverse events is strengthened by sharing of housing costs, and the 'insurance' of more than a single income.

Couple household dissolution, through divorce or separation, has been observed to have adverse consequences for the wealth position of each partner (Hendershott et al., 2009), with tenure change noted for at least one if not both former partners (Feijten, 2005; Feijten and Mulder, 2005; Babacan et al., 2006; Chamberlain and MacKenzie, 2006; de Vaus, et al., 2007; Dewilde, 2008; Gram-Hanssen and Bech-Danielsen, 2008; Wood et al., 2008; Feijten and van Ham, 2010; Mulder and Wagner, 2010). Divorcing or separating women with children in Australia are more likely to receive the family home in the property settlement than men (Sheehan and Hughes, 2001). Nevertheless, there are indications that many women subsequently fall out of home ownership (Beer and Faulkner, 2009). Women have been found to experience more difficulties with mortgage arrears in the aftermath of adverse events (Christie, 2000), and are less likely than widowers or male divorcees to replace housing equity withdrawn when a male partner leaves or dies (Babacan et al., 2006).

Family conflict and change in household size are significant push factors for women entering public housing and assisted private rental (Burke et al., 2004). Sole parents, of whom the great majority are women, experience higher than average mobility (Burke and Hulse, 2002) and tend to concentrate in poorer outer suburban locations, and inland and coastal regional centers, reinforcing detachment from the labour market (Birrell and Rapson, 2002).

Re-partnering has been shown to recoup some of the losses of dissolution, with former partners who remain single experiencing more severe hysteresis than those who re-partner (Painter and Lee, 2009). As men are more likely to re-partner than women, a gendered housing wealth gap is created, thereby creating demand by women for housing assistance (Wood et al., 2008). By retirement, there are significant differences in assets and debt held by men and women, with women holding far fewer assets (predominately only their home) (Jefferson and Ong, 2010).

Despite housing being the key strategy for saving for retirement, 'home ownership rates are in long run decline across all age groups other than over 65 years of age group' (Wood et al., 2014b: 39), and households are increasingly retiring with housing debt (Wood et al., 2010). Retirement savings are often used to meet debt obligations when partners die or leave (Wood et al., 2008). The need for housing assistance is often driven by disability, poor health and unemployment, (Bridge et al., 2002; Dockery et al., 2008; Berry et al., 2010; Tually, et al., 2011; Rowley and Ong, 2012), classic critical life events. Homeowners who exit into private rental are more likely to require housing assistance than longer-term private tenants, suggesting the impact of traumatic event(s) are cumulative (Wood et al., 2010).

Female caregivers are often required to relinquish paid work in order to provide care (Hulse and Saugeres, 2008a,b; Austen and Ong, 2009; McFerran, 2010; Sharam, 2011). 
Women at midlife find care obligations and poor health reduce their ability to return to work, and subsequent improvements in their health fail to increase their chances of entering employment (Austen and Ong, 2009), suggesting the cumulative impacts of critical life events can be different for men and women.

While employment is a key strategy by which households can obtain savings, and additional work is a means to overcome the financial impacts of critical life events, the labour market is also an increasing source of adverse critical life events. The shift from centralised wage fixing and tariff protection for local industry, to a more open, globalised economy has resulted in the decline of manufacturing and the growth in service industries with a concomitant loss of full-time jobs, and growth in part-time work, especially casual work, thus increasing labour market 'flexibility' (Wood and Ong, 2012). Underemployment, one of the most serious consequences of increasing labour market flexibility, has adversely affected housing security, with the worst affected being singleincome households, which are typically female lone-person or lone-parent households (Campbell et al., 2014).

The housing market itself is a source of adverse critical life events with evictions, rental increases, low vacancy rates, price inflation, mortgagee repossession and housing stress (paying more than 30 per cent of their income in housing costs) increasingly common. Private tenants face difficulties sustaining tenancies as a result of the combination of labour market conditions, poor health or disability and rental increases (Stone and Sharam, forthcoming). The digression between incomes and housing prices means that the average weekly earnings multiple required to buy a median priced house increased from 3.3 in September 1985 to 8.2 in June 2010 (Worthington, 2012: 239). The average weekly earnings multiple, a common housing affordability measure, assumes full-time employment but takes no account of a persistent gender pay gap of around 17 per cent (WGEA, 2014).

Critical life events, such as changes in household formation, employment, caregiving, health and disability, have been identified by housing researchers as triggering changes in housing pathways. Longitudinal data, in particular, has enabled researchers to appreciate the cumulative impacts of events, and has highlighted gender differences. The focus groups, which are discussed next, draw attention to household dissolution and caregiving, economies of scale in consumption, the housing market and the impact of changes to the labour market.

\section{The focus groups}

The focus groups followed an earlier survey of single Victorian women over the age of forty years, with or without children, who did not believe they would own their housing outright when they retired (Sharam 2011). The current focus groups (Sharam 2015) were intended to provide more nuanced data about midlife single women, particularly with regard to their capacity to participate in a shared equity, home ownership scheme. Women were primarily recruited via advertising (with women's and housing organisations playing a key role in promoting the research), and through direct email where they had previously made contact with the researcher (in relation to previous research or publications). Around sixty women responded and were asked about days and times that would be convenient to them, and session times were chosen on the basis of availability. Nevertheless, there was considerable dropout. Five focus groups were conducted throughout 2012. Four were 
held in Melbourne, the capital of Victoria, and one in a regional city. A total of thirty women participated. The women were aged between forty and sixty-five.

In the focus groups, the women were asked about their attitudes to home ownership, about saving and money and what they would be prepared to forgo in order to save, any requirements to support other people, what their financial strategy for retirement was and, finally, their interest in the equity land trust housing model. The resulting data were transcribed and analysed using NVivo software.

In terms of income, a small number were on pensions or unemployment benefits. Most were employed, with remuneration between $\mathrm{A} \cup \$ 40,000$ and $\mathrm{A} \cup \$ 90,000$ per annum. The majority were in private rental housing, and three had mortgages (recent purchases). Two purchasers and some of the renters were in severe housing stress. Some of the private renters had been in their current tenancy for many years, and their rents were well below the market rate. Many were sharing, either in 'group' households with unrelated others, or with family (mostly adult children), enabling economies of scale in consumption. A small number were single parents with dependent children living with them, but a much larger number were single parents whose children had moved out of the home.

The women's earlier life-course trajectories involved either partnering (and having children or not having children), purchasing or renting housing, separation or divorce and loss of housing equity if they had purchased; or not partnering (for cohabitation) and renting. Purchasing was often, but not always, associated with the birth of children, but it was while they were younger and always with a partner. Home purchase (actual or envisaged) was inextricably linked to partnering.

So I somehow thought you leave year 12 and you magically get married, have kids and have a house and a car. I didn't know the way it worked, which is very naïve ... So I guess I try not to feel like a loser that I haven't got a home or probably never will have a home because I didn't have the foresight to think about that in my twenties.

Even as the women moved out of their twenties and thirties, and out of relationships, the connection between partnering and home purchase remained.

I just wanted to make one comment that as a single female, I became single in $2003 \ldots$. I I was just hooked on - I'll meet someone and combine an income, but I found that you just can't bank on that, and you just have to set up your own.

This belief in waiting for a 'white knight' (a male to rescue them) is, anecdotally, not uncommon (Sharam, 2011). It reflects a control belief about what constitutes a normative life-course. Not partnering, with its psychological, social and material ramifications, is a critical life event, and while it reflects a fundamental social change, it is not necessarily a choice.

In contrast, a number of women had shared housing for many years as much as a matter of preference as of financial need. These women had control beliefs that meant they could adopt strategies that better enabled them to cope with rising rental costs, and, as we shall discuss shortly, increasingly precarious work.

The cumulative impact of critical life events and control beliefs is evident in the following comment with the loss of partner resulting in an initial loss of wealth and 
further losses associated with being unable to work, and the very considerable increase in house prices during this period:

I came out of a marriage in 2004, and came out with a bit of money, and saw a financial advisor, and he said, 'Well what do you want, [name]? Do you want, at the moment, like you've been married for 26 years, do you want a lifestyle, or do you want to use this for a deposit for a little place, and really struggle, like really, financially struggle.' And so I picked the lifestyle, and put my money into long term investment, and then I started sharing rent, and I've lived everywhere, and I became the littlest hobo, and I tired of that after - got really tired after about four years. So then I looked at pulling my money out, and I got sick, and I was off work for four months, so I actually inquired about my super, so I got enough money together to pay a ten percent deposit on a little place by drawing most of my money out of super, and out of my savings.

Eight women had previously purchased housing and subsequently fallen out of home ownership. Each had purchased with a partner, and the subsequent loss of their home was related to separation, divorce or death of that partner. Most indicated that they received little equity as part of the property settlement. In one case, the loss of housing equity related to the housing market, to a period of very high interest rates in the early $1990 \mathrm{~s}$ and repossession:

I've had two household mortgages with two different marriage partners in my lifetime and there's nothing of that left because of interest rates hiking up at one stage. We were spending more than half of his income on the mortgage that we were paying out on and at the end of the year when the statement came in, we'd paid out some ridiculous amount of money, but we'd only paid $\$ 200$ off the loan of the house. But we'd gone without every month to just try and stay in that house.

For those women who had children, the impact of losing their partner was severe as they lost economies of scale in consumption, and their ability to earn an income was highly constrained by the need to provide care for their children. Many funded their current household expenditure using debt, with repayments consuming a percentage of household budgets for many years. The need to provide for children, moreover, did not necessarily end once the children had left home, and a number of women continued to assist grown children with the costs of education and housing.

I thought once they finished school, 'Off you go, look after yourselves, bye' ... No. They come and go. It's just so different to when I was that age. I thought she'd just be at a part-time job, look after - she was sharing this place that's going to be pulled down and everything so she couldn't have gotten cheaper rent and still couldn't afford to support herself entirely which was a big shock for me, so reluctantly, about a year later, she's been evicted back so I acknowledge that they need help to get through uni.

Some of these women could not afford the financial support they were providing to their children:

I don't save. I almost never go out. I've got two university-aged daughters that I assist with their living expenses. 
Some women, however, were attempting to ensure their children had the housing security they did not, and were making very significant sacrifices:

My son ... He's always needed money. So that's always been a burden on my own pocket, and when he wanted to buy his first home with his new partner, again he asked - he asked to lend \$10,000 and you know, I went on this big guilt trip, and I had no money, and I had this plan I'd buy my own little place with $10 \%$ deposit, and I ended up giving him $\$ 5,000$ as a gift.

While these trajectories often included housing insecurity, only one woman mentioned being homelessness. As a person with mental health issues, she fits a known homelessness 'pathway' (Chamberlain and Johnson, 2013), and as such was atypical of the women in the focus groups.

The acquisition of housing equity by women had been adversely affected by critical life events: loss of partner, birth and care of children, or never partnering and the housing market. Whatever aspirations the women had had in recent years to purchase, their hopes had largely been dashed by the dramatic rise in house prices. Some were already experiencing housing stress and all were worried about being impoverished in retirement. Yet, most of the women were tertiary educated and many were working in professional fields. Surely, these attributes should mean they are less vulnerable to homelessness?

\section{Education and employment}

The survey of single women over forty years of age (Sharam 2011) found 75 per cent of the responding women had post-secondary school qualifications. This held true for the women participating in the focus groups; very few did not have at least a post-secondary school certificate, diploma or degree. Mostly they held degree-level qualifications, and some had double degrees or had started post-graduate degrees. These findings are consistent with earlier research that found divorced women who remained single have the highest education levels of all Australian women (de Vaus et al., 2007).

Most of the younger women, those in their forties, appeared to have transitioned immediately to tertiary education after completing secondary school. The women aged over fifty, however, had returned to education as mature students. For some of these it was a deliberate strategy to improve their income. Others also saw the opportunity provided by free university education as about broader concepts of self-improvement and self-fulfillment.

The women who partnered and had children early, who then became single parents, were particularly passionate about education. These women had been reliant on the 'single mothers pension' (now the Parenting Payment) when their children were young, but given the inadequacy of this benefit they also needed to work to support their children. The kinds of work they could obtain that provided the flexibility to care for their children were typically in low-paid 'female' jobs. Education was viewed as the longer-term solution. One woman sold her house in Perth specifically to fund her university course:

The equity that I had I thought would last maybe three years, re-qualify, so I did a degree, and thinking that then I can get a better paying job, and then I'Il just buy back in. 
Obtaining qualifications however generally meant considerable sacrifice:

I left school at 16 with a Year Nine education, and had my first daughter at 19, and then had my second daughter at 21 , and then was divorced by the time I was $24 \ldots$ [at] 35 I was working as a barmaid, and worked as a cleaner, and in a cake shop, and eventually got a bank job as a teller in a bank, and knew all along that I needed to get an education to try to do better for myself, and my girls, so I took myself back to university ... but by that stage the financial stress of - at one stage we were living on $\$ 11,000$ per annum.

Single parents typically struggled to make ends meet, and debt was used to make ends meet:

When I was a single parent, and especially going through my second degree, and even my first few years of working, when income was about $\$ 30,000$, you do, a lot of things go on your credit card, bills and that, and I had two, and I think between them they got up to about $\$ 7,000-\$ 8,000$ and there was a loan.

Once they had qualified and started working, debt was a legacy problem that needed to be addressed before savings could be accumulated:

I'm still paying off a HECS debt, and a Commonwealth debt, because there was a period of time where the government would give you, if you're on a single Mother's pension, they would give you a little bit extra for education, but they would give you a little bit more than extra if you agreed to pay it back later, so it came out of my degree with, in total, around $\$ 30,000$ debt. So I'm still paying that off. Plus the credit card debt, and the little Mazda that I'm paying off.

Having gained an education, a number of the women were in professional roles, and were earning a good income. One woman said her income had increased by $\$ 30,000$ over the past five years:

I agree with you, it was a really positive experience for me, and it enabled me to get the income I'm on now.

But they were now in the latter part of their working lives, and they knew they had insufficient working years ahead to acquire housing:

So my income now is really good, but it's kind of, at the tail end.

During this period house prices rose dramatically, blocking aspirations to purchase:

By the time you finish your education ... houses have not just doubled - the prices, they've quadrupled, so it again puts it out of your reach.

The women believed in education for its own sake, and for the economic benefits that could be derived from holding qualifications. The latter was particularly important for women with children. These important control beliefs meant they were willing to make considerable sacrifices. Impossibly high housing prices, however, were not the only critical life event that impacted on them. 
Extensive casualisation of employment and industry restructuring resulted in increased precariousness of employment, with many of the women working far fewer hours than they wanted, and facing downward pressure on wages:

I'm only on a monthly contract which has been going for almost two years and it's government department, so they don't pay me enough money to be able to have a big social life.

Like women more generally, the women in the focus groups work in female dominated industries such as teaching, health and retail that pay lower wages than available in 'male' industries.

I work casually in TAFE [Tertiary Education and Further Education sector] and I try and work up to an equivalent of full-time so in the last 20 years I've had two one-year full-time contracts and I've had a couple of short-term full-time things, like six weeks but otherwise I might be working for three or four or five employers in a year ... I do everything like that I can. I tutor people in year 12 English to get extra money but try and bring my income up to what a full-time teacher would get but it's not that high.

The Australian labour market is highly sex segmented, with around 46 per cent of female employees concentrated in just three industry sectors: health and social assistance, education and training and retail trade (Australian Bureau of Statistics, 2011). Those jobs, as Sheen (2010) notes, are increasingly precarious, with women's employment increasingly part-time, with 58 per cent of these part-time jobs also being casual; around 30 per cent of employed women are casual workers compared with 22 per cent of employed men. The gender wage gap and employment precariousness is exacerbated by caregiving.

My daughter was in hospital for four months. I had to forego a promotion, which ultimately led to redundancy because the whole department moved, and instead of taking me with it, I had to just let it go, because I couldn't with my child in the condition [she] was.

New qualifications and more highly skilled jobs were instrumental for improving the economic position of the women who had lost a partner. This new earning capacity, however, was gained too late to avoid being priced out of the housing market. But the choice of most of the women to work in female sex-segregated industries has not only meant being subject to discriminatory lower wages, but also to increasing employment precariousness. Lower lifetime earnings (compared to men) are reflected in them having very low superannuation accounts, increasing their future reliance, in retirement, on the age pension. Even with Rental Assistance rebates from the Australian Government, age pensioners paying even a modest sum for private rental have only around two-thirds of the after-housing income of home-owning age pensioners, and are worse off than age pensioners in public rental. ${ }^{1}$

Retirement, therefore, was an anxiously anticipated critical life event. Those who were currently working said retirement was not an option, that they would need to keep working.

So the strategy for retirement is not to retire. I'll just keep working and being self-employed, I can work until I'm 75 and then top myself or something, whatever. 
The women did not have, as Jopp and Schmitt (2010) describe it, command over the material resources critical for adapting to an indefinite period on a low income with high housing costs. Education had been highly beneficial, but its value was undercut by employment precariousness, by housing shock, and by gender discrimination.

\section{Conclusion}

The life experiences of the women in the focus groups reflected the adverse impacts of critical life events and demonstrated how such impacts can accumulate over time. Specifically, the women who partnered and had children and who then lost that partner, either through divorce, separation or death, were very adversely affected in financial terms. In many cases, the loss of a partner resulted in a loss of housing equity and tenure change for those who had been purchasing. This group could have otherwise expected to accumulate housing equity and to enter retirement with full home ownership and the benefits that brings. Instead, raising children on their own meant low-paid work with flexible (mostly part-time) hours. The coping strategies adopted included short to mediumterm sacrifices to gain qualifications that would permit them to gain better-remunerated employment. Some of the mothers also supported adult children through university. This reflects a key 'control belief' that education is of enormous value, both economically and personally. Of the women who did not have children, some had had partnerships and had purchased but lost equity when those partnerships ended. Like the single parents, these women also valued education, and often sacrificed earnings in order to obtain qualifications.

While tertiary education improved their longer-term prospects, most women went into sex-segregated employment where wages are substantially lower than average male weekly earnings. So, while the women gained benefits from their education, gender discrimination tended to reduce the economic benefit of their education.

Changes in labour market conditions are also critical life events, and increased labour market flexibility has reduced hours of work and job security for many, driving, as Sheen (2010) argues, increased employment precariousness in Australia, the brunt of which is experienced by women, with housing insecurity implications (Campbell et al., 2014). The low lifetime earnings of the women, and the consequential low level of superannuation, amply demonstrate the cumulative effects of critical life events. In terms of policy responses, the current promotion of education as a pathway out of homelessness, needs to recognise the labour market as source of risk, not just of opportunity.

Fear of the future, in which living in private rental housing and being reliant on the age pension would impoverish them, was uppermost in their minds. All the women looked at retirement as the next known critical life event; one they were financially ill prepared for, and for which they alternated between trying not to think about and brutal realism.

The evidence provided by the focus groups reflects much of what is understood in housing research about the nexus between partnering, loss of partner, not partnering and housing equity. Similarly, housing researchers have noted the impact of increasing labour market flexibility on housing insecurity. This article argues that the critical life events framework is a useful method by which we can understand disruptions to peoples' lives, and draws attention to the importance of control beliefs in adapting to adverse events. But 
it also highlights the limitations on individual agency: how gender discrimination, labour market flexibility and costly housing can undercut self-determination.

Welfare policy that assumes individual ownership of significant assets as the basis of retirement must be highly attentive to the income security required over a lifetime to fund housing acquisition. Accordingly, policy needs to take account of gendered housing pathways. The application of a gender-lens would bring attention to the gender pay gap, the limitations of occupation-linked superannuation, the sharing of childcare and paid parental leave as issues affecting the capacity of women to accumulate savings. What this article adds is awareness that precarious employment is also a gender issue, one that diminishes the economic gains made by women through pursuing further education. Current welfare policies in Australia, inspired by neo-liberal ideology, have encouraged self-provisioning via asset accumulation for retirement. But neo-liberal labour market reforms have also undermined the ability to save, locking many single women out of home-ownership and thus a secure retirement.

\section{Acknowledgements}

This preparation of this article was generously supported by the Jean McCaughey Social Justice Sub-Fund (The Victorian Women's Benevolent Trust).

\section{Note}

1 As of December 2014, a single age pensioner receives $\$ 22,211$ per annum. Those who rent receive a maximum additional payment in Rental Assistance of $\$ 3,317$. The median rent for a one bedroom flat in metropolitan Melbourne as of September 2014 was AU $\$ 309$ per week (or \$16,068 per annum). Source: Rental Reports 2014, Department of Human Services, http://www.dhs.vic.gov.au/about-thedepartment/documents-and-resources/research,-data-and-statistics/rental-reports-2014.

\section{References}

AlHW (Australian Institute for Health and Welfare) (2014) Housing Outcomes for Groups Vulnerable to Homelessness, Canberra: Australian Government.

Ajzak, I. (1991) 'The theory of planned behavior', Organizational Behavior and Human Decision Processes, $50,2,179-211$.

Allen, C. (2000) 'On the "physiological dope" problematic in housing and illness research: towards a critical realism of home and health', Housing, Theory and Society, 17, 2, 49-67.

Austen, S. and Ong, R. (2009) 'The employment transitions of mid-life women: health and care effects', Ageing and Society, 30, 2, 207-27.

Australian Bureau of Statistics (2011) Census of Population and Housing 2011, Canberra: ABS.

Australian Government (2008) The Road Home: A National Approach to Reducing Homelessness, Canberra: Commonwealth of Australia.

Babacan, A., Chamberlain, C., Cullen, G., Dockery, M., Stoakes, A. and Wood, G. (2006) The Implications of Loss of a Partner for Older Private Renters, Positioning Paper No. 93, Melbourne: AHURI.

Baxter, J., Qu, L., Weston, R., Moloney, L. and Hayes, A. (2012) 'Experiences and effects of life events', Family Matters, 90, 6-18.

Beer, A. and Faulkner, D. (2009) 21st Century Housing Careers and Australia's Housing Future, Final Report No. 128, Melbourne: AHURI.

Berry, M., Dalton, T. and Nelson, A. (2010) Mortgage Default in Australia: Nature Causes and Social and Economic Impacts, Final Report No. 145, Melbourne: AHURI. 
Birrell, B. and Rapson, V. (2002) The Location and Housing Needs of Lone Parents, Final Report No. 7, Melbourne: AHURI.

Bridge, C., Kendig, H., Quine, S. and Parsons, A. (2002) Housing and Care for Younger and Older Adults with Disabilities, Final Report No. 16, Melbourne: AHURI.

Burke, T. and Hulse, K. (2002) Sole Parents Social Wellbeing and Housing Assistance, Final Report No. 15, Melbourne: AHURI.

Burke, T., Neske, C. and Ralston, L. (2004) Entering Rental Housing, Final Report No. 59, Melbourne: AHURI.

Campbell, I., Parkinson, S. and Wood, G. (2014) Underemployment and Housing Insecurity: An Empirical Analysis of HILDA Data, Final Report No. 230, Melbourne: AHURI.

Chamberlain, C. and Johnson, G. (2013) 'Pathways into adult homelessness', Journal of Sociology, 49, 1, 59-76.

Chamberlain, C. and MacKenzie, D. (2006) 'Homeless careers: a framework for intervention', Australian Social Work, 59, 2, 198-212.

Christie, H. (2000) 'Mortgage arrears and gender inequalities', Housing Studies, 15, 6, 877-905.

COAG (Council of Australian Governments) (2008) National Partnership Agreement on Homelessness, Canberra: COAG, http://www.federalfinancialrelations.gov.au/content/npa/housing/homelessness_ superseded/national_partnership_superseded.pdf [assessed 02.10.2015].

Crinall, K. (2001) 'Representing the invisible: images of women among the "new" faces of homelessness', Parity, 14, 1, 7-90.

Darab, S. and Hartman, Y. (2013) 'Understanding single older women's invisibility in housing issues in Australia', Housing, Theory and Society, 30, 4, 348-671.

de Vaus, D., Gray, M., Qu, L. and Stanton, D. (2007) The Consequences of Divorce for Financial Living Standards in Later Life, Australian Institute of Family Studies Research Paper no. 38, Melbourne: Australian Institute of Family Studies.

Dewilde, C. (2008) 'Divorce and the housing movements of owner-occupiers: a European comparison', Housing Studies, 23, 6, 809-32.

Dockery, A., Feeny, S., Hulse, K., Ong, R., Saugeres, L., Spong, H., Whelan, S. and Wood, G. (2008) Housing Assistance and Economic Participation, National Research Venture 1, Melbourne: AHURI.

Flatau, P., Hendershott, P., Watson, R. and Wood, G. (2004) What Drives Australian Housing Careers, Final Report No. 68, Melbourne: AHURI.

Feijten, P. (2005) 'Union dissolution, unemployment and moving out of homeownership', European Sociological Review, 21, 1, 59-71.

Feijten, P. and Mulder, C. H. (2005) 'Life-course experience and housing quality', Housing Studies, 20, 4, 571-87.

Feijten, P. and van Ham, M. (2010) 'The impact of splitting up and divorce on housing careers in the UK', Housing Studies, 25, 4, 483-507.

Gram-Hanssen, K. and Bech-Danielsen, C. (2008) 'Home dissolution: what happens after separation?', Housing Studies, 23, 3, 507-22.

Green, M. (2009) 'The social distribution of harm', in D. Hume and R. Kanbar (eds.), Poverty Dynamics, Oxford: Oxford University Press, pp. 309-27.

Hendershott, P. H., Ong, R., Wood, G. A. and Flatau, P. (2009) 'Martial history and home ownership: evidence from Australia', Journal of Housing Economics, 18, 1, 13-24.

Hulse, K. and Saugeres, L. (2008a) Home Life, Work and Housing Decisions: A Qualitative Analysis, Research Paper No. 7, Melbourne: AHURI.

Hulse, K. and Saugeres, L. (2008b) Housing Insecurity and Precarious Living, Final Report No. 124, Melbourne: AHURI.

Jefferson, T. and Ong, R. (2010) Profiling Gender Differentials in Asset and Debt Portfolios in Australia, Working Paper Series 201004 March, Perth: Centre for Research in Applied Economic Curtin University of Technology.

Jopp, D. and Schmitt, M. (2010) 'Dealing with negative life events: differential effects of personal resources, coping strategies, and control beliefs', European Journal of Ageing, 7, 3, 167-80. 
McFerran, L. (2010) It Could Be You: Female, Single Older and Homeless, Sydney: Homelessness NSW and Older Women's Network NSW.

Moloney, L., Weston, R., Qu, L. and Hayes, A. (2012) Families, Life Events and Family Service Delivery, Canberra: Australian Institute of Family Studies.

Mulder, C. and Wagner, M. (2010) 'Union dissolution and mobility: who moves from the family home after separation?', Journal of Marriage and Family, 72, 5, 1263-73.

Olsberg, D. (2004) 'Women and superannuation: still Ms... ing out', Journal of Australian Political Economy, 53,161-78.

Painter, G. and Lee, K. (2009) 'Housing tenure transitions of older households: life cycle, demographic, and familial factors', Regional Science and Urban Economics, 39, 6, 749-60.

Rowley, S. and Ong, R. (2012) Housing Affordability Housing Stress and Household Wellbeing in Australia, Final Report No. 192, Melbourne: AHURI.

Sharam, A. (2008) Going It Alone: Single, Low Needs Women and Hidden Homelessness, Melbourne: Women's Information Support and Housing in the North.

Sharam, A. (2011) No Home at the End of the Road: A Survey of Single Women Over 40 Years of Age Who Do Not Believe They Will Own Their Housing Outright at Retirement, Melbourne: Salvation Army Southern Territory and Swinburne Institute for Social Research.

Sharam, A. and Hulse, K. (2014) 'Understanding the nexus between poverty and homelessness: relational poverty analysis of families experiencing homelessness in Australia', Housing, Theory and Society, 31, 3, 294-309.

Sharam, A. (2015) The Voices of Midlife Women Facing Housing Insecurity, Melbourne: Institute for Social Research.

Sheehan, G. and Hughes, J. (2001) Division of Matrimonial Property in Australia, Research Paper No. 25, Melbourne: Australian Institute of Family Studies.

Sheen, V. (2010) 'The social risks of precarious employment for women', Emerging Trends in Times of Instability: New Challenges and Opportunities for Social Security, International Social Security Association, 6th International Policy and Research Conference on Social Security, Luxembourg, 29 September to 1 October, http://www.voced.edu.au/content/ngv45392 [accessed 10.01.2015].

Stefanek, E., Strohmeier, D., Fandrem, H. and Spiel, C. (2012) 'Depressive symptoms in native and immigrant adolescents: the role of critical life events and daily hassles', Anxiety, Stress, and Coping, $25,2,201-17$.

Stone, W. and Sharam, A. (forthcoming) Critical Life Events and Housing Shocks in the Private Rental Sector, Melbourne: AHURI.

Tually, S., Beer, A. and Faulkner, D. (2007) Too Big to Ignore, Future Issues for Australian Women's Housing 2006-;2025, Adelaide: AHURI Southern Research Centre.

Tually, S., Beer, A. and McLoughlin, P. (2011) Housing Assistance Social Inclusion and People Living with a Disability, Final Report No. 178, Melbourne: AHURI.

Turner, J., Goodin, J. and Lokey, C. (2012) 'Exploring the roles of emotions, motivations, self-efficacy, and secondary control following critical unexpected life events', Journal of Adult Development, 19, 4, 215-27.

Wood, G., Colic-Peisker, V., Berry, M., and Ong, R. (2010) Asset poverty and older Australians' transitions onto housing assistance programs, Final Report No. 156, Melbourne: AHURI.

Wood, G., Ong, R. (2012) Sustaining Home Ownership in the 21st Century: Emerging Policy Concerns, Final Report No. 187, Melbourne: AHURI.

Wood, G., Ong, R. and Cigdem, M. (2014b) Housing Affordability Dynamics, Final Report No. 233, Melbourne: AHURI.

Wood, G., Batterman, D., Cigdem, M. and Mallett, S. (2014a) The Spatial Dynamics of Homelessness in Australia 2001-;2011, Final Report No. 227, Melbourne: AHURI.

Wood, G., Colic-Peisker, V., Berry, M. and Ong, R. (2010) Asset Poverty and Older Australians Transitions into Housing Assistance Programs, Final Report No. 156, Melbourne: AHURI. 
Wood, G., Chamberlain, C., Babacan, A., Dockery, M., Cullen, G., Costello, G., Nygaard, A., Stoakes, A., Adam, M. and Moloney, K. (2008) The Implications of Loss of a Partner for Older Private Renters, Final Report No. 116, Melbourne: AHURI.

Workplace Gender Equality Agency (WGEA) (2014) Gender Pay Gap Statistics, https://www.wgea.gov. au/sites/default/files/2014-03-04-Gender_Pay_Gap_factsheet_website.pdf [accessed 10.01.2015].

Worthington, A. (2012) 'The quarter century record on housing affordability, affordability drivers, and government policy responses in Australia', International Journal of Housing Markets and Analysis, 5, 3, 235-52. 